\title{
Agency and positioning in a multilingual mathematics classroom
}

\author{
Eva Norén ${ }^{1}$
}

Published online: 13 April 2015

(C) Springer Science+Business Media Dordrecht 2015

\begin{abstract}
This paper draws on data from a first grade multilingual mathematics classroom in Sweden. I explore how students' agency is pronounced in the classroom that actually can be a site where mathematics reform-oriented pedagogy thrives and how the emphasis on language support in such classrooms can support reform-oriented pedagogy. I argue that the emphasis on reform-oriented pedagogy can support the learning of mathematics and a second language, simultaneously. By analysing discursive practices, I show how this supportive relationship operates alongside the on-going processes of normalisation whereby students' mother tongues continue to be erased or ignored.
\end{abstract}

Keywords Mathematics - Language-oriented $\cdot$ Reform-oriented $\cdot$ Foucault $\cdot$ First grade classroom

Due to dramatic increases in immigration, almost a fifth of all students in Swedish compulsory school, speaking more than 100 languages, have a mother-tongue other than Swedish (Skolverket ${ }^{1}$, 2013). However, despite legislation permitting them "to receive support for the development and use of their languages" (Ganuza \& Hedman, 2015, p.125), a disproportionately high number fail to meet the national assessment benchmarks that would enable them to progress from compulsory to senior high school (Skolverket, 1997, 2007). In today's Sweden, teachers are expected to support second language learners' acquisition of Swedish through language-orientated teaching in all school subjects (Hajer, 2003; Lindberg, 2009), expectations that presuppose that subject teachers understand the complex relationship between language and learning. In the case of mathematics, language subject teaching (Barwell, 2005) resonates with reform-oriented mathematics teaching, which is characterised by emphases on communication and collaboration (Moschkovich, 1999). In this paper, the first such study in the

${ }^{1}$ In English: National Agency of Education

Eva Norén

eva.noren@mnd.su.se

1 Department of Mathematics and Science Education, Stockholm University, 10691 Stockholm, Sweden 
Nordic countries, I examine the complex relationships in a first grade multilingual Swedish mathematics classroom ${ }^{2}$.

\section{Multilingualism in mathematics classrooms}

Increasingly and internationally, mathematics is being taught in linguistically and culturally diverse contexts, with the consequence that research on mathematics education and language diversity is growing rapidly. For example, the field now covers areas like language and meaning making (Khisty, 1995), mathematical text problems (Barwell, 2009), mathematics teaching and culture (Civil, 2002), conversation support (Moschkovich, 2008), language policy (Setati, 2008), bilingual teaching (Jones, 2000) and more. Indeed, Setati, Nkambule and Goosen (2011) observe that research has addressed issues as diverse as the role of language negotiations in a multilingual mathematics classroom, language policy and the teaching and learning of mathematics, discursive issues in mathematics problem solving, mathematics and culture in Micronesia, Latinos in mathematics classrooms, modality in French immersion mathematics, exploratory talk, discourse switch, the use of first language Turkish as a resource, students' code switching in mathematics problem solving, to methodological issues in research on language and learning mathematics. Importantly, with respect to this study, a recurrent feature is that multiculturalism and multilingualism need not imply disadvantage but should be seen as resources for teaching and learning. For example, Clarkson (2007) showed how high-performing grade four students of Vietnamese background were able to use English and Vietnamese in their mathematics learning in Australian classrooms. These students were more confident solving complex problems than monolingual English-speaking students, not least because they had been permitted to use both languages. Interestingly, by their later school years, they used predominately English, emphasising the extent to which they felt integrated. This resonated with earlier studies showing that "the competencies that the students have with both their languages are important in how well they perform mathematical tasks" (Clarkson, 2007, p. 212). Thus, evidence suggests that research conducted within a sociocultural frame, research that foregrounds the resources multilingual students bring to school rather than any sense of deficit (Moschkovich, 2007a, 2011), circumvents the negative. That is, in promoting students' everyday life experiences and prior linguistic and cultural backgrounds (Moschkovich, 2002, 2007a, b), the focus is on "progress in what learners already know and do" (Moschkovich, 2012, p. 91). Embedded in such analyses is the assumption that students' proficiency in their first language is crucial for second language learners (Cummins, 1996).

However, in more negative vein, relations between language and power are implicit in several of the above studies and, while manifested in different ways, they influence greatly the opportunities afforded to multilingual students in mathematics classrooms worldwide. For example, Stathopoulou and Kalabasis (2007) investigated Romany students in a first grade Greek mathematics classroom in which their first language, which was not Greek, and their cultural experiences were ignored. Greek teachers taught as though the Romany students were "tabula rasa" (p. 235), as if they came to school with no language and no every-day or out-ofschool knowledge. In schools, the Greek language was connected with status and power as

\footnotetext{
${ }^{2}$ According to Barwell (2009) a multilingual classroom is any classroom where more than one language can be used, and of course, classrooms where more than one language is used.
} 
well as with education and social progress. However, the practices had negative consequences for the Romany students as they had to cope with the school's refusal to allow them to use their first language and the rejection of characteristics of their culture, such as oral traditions.

Significantly, the development of school-related language requires considerably more time than the development of everyday, interactional, language (Cummins (1979, 1996, 2000; Thomas $\&$ Collier 2001). Indeed, conversational proficiency in the language of instruction typically takes about 2 years, while academic proficiency make take five or more (Cummins, 2008). Consequently, it is important that second-language speakers be encouraged to use both languages in all aspects of their learning. Moreover, from the perspective of mathematics, teachers' difficulties are compounded by their having to address three inter-related dilemmas when working in multilingual classrooms (Adler, 2001). These are code switching (whether or not and when to switch languages), mediation (shifts towards learner-centred practices, context neutrality, taken for granted communicative competence) and transparency (language as means of communication, clarity and access to mathematical discourse, explicit mathematical language).

\section{Multilingual classrooms in Sweden}

Research in Sweden, some of which has confirmed the challenges faced by students in having to use a second, partially understood, language to study all other school subjects (Otterup, 2005), shows that immigrant students' linguistic and cultural backgrounds are often viewed as deficiencies that contribute to low performance. For example, a lack of Swedish-ness (Sjögren, 1996, 1997; Parszyk, 1999; Haglund, 2005) positions students as immigrants and teachers' well-meaning attempts to remove their non-Swedish attributes limit students' space for agency (Runfors, 2003). Such normalising discourses, promoting monolingualism and Swedish-ness, lead to multilingual students feeling not only less "valued" or less empowered than students of Swedish-born parents (Gruber, 2007) but that school is "not for them" but for "the Swedes" (Parszyk, 1999). Moreover, the greater the difference between minority students' culture and Swedish culture the harder it is for them to solve standard Swedish text problems, not least because instruction and its related artefacts are based on mainstream Swedish perspectives (Parszyk, 1999). Other studies have highlighted how different ways of speaking Swedish are valued and practiced, whereby students', in this case boys', mother tongue and their peers' language are subordinated to "pure" Swedish, "the Swedish of the Swedes" (León Rosales, 2010, p. 325).

While much research has focused on attributionist explanations, some Swedish studies have disrupted that view by means of alternative readings of the lives and experiences of multilingual students with mathematics. For example, despite the strength of the dominant and discriminatory deficit-focused power relations evident in many classrooms, students, like all social actors, are able to respond to and even resist such dominant deficiency discourses (Haglund, 2005). Indeed, there is evidence that students taught in multilingual classrooms find the experience enriching (Otterup, 2005; Norén, 2010).

\section{Theoretical context}

In addition to acknowledging the sociocultural nature of the resources students bring to their classrooms (Moschkovich, 2002, 2007a, b), this study has been inspired by mathematics 
education research focused on understanding the manifestation and role of power relations in mathematics classrooms (Walkerdine, 1988; Hardy, 2004; Cotton \& Hardy, 2004; Meaney, 2004; Walshaw, 2007). In this respect, and drawing on Foucault (1972), power is the relational capacity of social actors to position themselves in different situations through the exercise of various discourses. In other words, power is in constant transformation and is distributed in social relations. As Foucault notes,

What characterizes the power we are analysing is that it brings into play relations between individuals or between groups [...] The exercise of power consists in guiding the possibility of conduct and putting in order the possible outcome [...] (Foucault, 1982, p. 217-221 in Cotton and Hardy, 2004, p. 91)

Defining power in this way provides a means for studying existing classroom practices in which people interact with each other. One aspect of classroom power relations is how teachers organise content, time and space. Power is a mechanism (Foucault, 1991) that enables people to act, and knowledge to be produced. When it comes to knowledge in the classroom, students play a part as well (Phillips Manke, 1997). Thus, while the effects of power are repressive they are ultimately productive. A key component of Foucault's (1972) arguments is that discursive practices differentiate people in relation to cultural norms, norms that have become regulatory and often self-regulatory ways of knowing. For example, Hardy (2004) writes of how the 1995 National Curriculum for Mathematics in England became a cultural norm. Its representation of mathematics as four content domains and eight levels of achievement came to be seen as the "normal" and obvious way of categorising mathematics and student achievement.

Another example, more explicitly linked to the aims of this study, can be found in Meaney's (2004) work with a Māori school community in which, by identifying spaces to ensure that their agendas for language development and modernizing were achieved, a Māori mathematics curricula for schools teaching in the Māori language was achieved (Meaney, 2004). Throughout her analyses, as "power circulated between us as knowledge was offered, rejected and used to develop other knowledge" (Meaney, 2004, p. 194), Foucault's power as productive was evident. She writes that power ebbed and flowed between participants as different forms of knowledge were: "offered, produced, modified and accepted" (p. 196). She concludes that when researchers engage with an unfamiliar community, they need to acknowledge embedded assumptions in order to avoid dominating behaviours that would limit community members' exercise of power - knowledge should be shared and trust established.

Finally, when students learn mathematics, they also acquire values that enable them to understand themselves in relation to the world and to other people (see also Popkewitz, 1987). In so doing, they position themselves and others in relation to discourse, a theme to which I return later. Also, while earlier studies provide insights on multilingual learners in mathematics classrooms, a Foucauldian analysis allows for the uncovering of power relations, wider societal issues and the impact of various discourses.

\section{Project aims}

From a Swedish perspective, where multilingual students' in mathematics classrooms are often conceived as deficient (Sjögren, 1997; Parszyk, 1999; Runfors, 2003; Haglund 2005), the field lacks research focusing on agency and power relations. In this study, therefore, my aim is to explore discursive practices in order to understand how students act and are positioned by 
enacted discourses in multilingual mathematics classrooms. The guiding questions are as follows:

- How do various discourses, in relation to classroom interaction, operate in a first grade multilingual mathematics classroom?

- How do these discourses relate to students' agency and positioning?

\section{Discourse}

According to Foucault (1971), discourses are construed as practices structured through power relations that enact different identities and positions. These practices, which "systematically form the objects of which they speak" (Foucault, 1972, p. 49), mould or shape the individuals acting them. That is, discourses exist through what Foucault calls the discursive practice, and each discourse has a function within this practice. Within such a framework, "it is discourse, not the subject who speaks it, which produces knowledge" (Foucault 1977, p. 79). In the particular context of mathematics education, discourse-related analyses frequently focus on cultural and social relations and the interactions of the macro processes of social and institutional actions (Ryve (2011). Other studies, at a micro level, have shown how classroom discursive practices position students' engagement as learners of mathematics (Solomon, 2007, 2008; Walkerdine, 1988; Walshaw, 2007). Thus, a students' experience of school mathematics is located in the interactions of both macro and micro discourses that create social positions and entail the negotiation of power relations. Power, in this Foucauldian sense, does not draw from authorities or laws, but emerges in the social practices that teachers and students take part in and create (Öhman, 2010). In this paper, acknowledging such traditions, I focus not only on the relationships between official and public discourses but also those discourses that are enacted in the discursive practices of one first grade, multilingual, mathematics classroom. In so doing, I construe mathematics education not only as a sociocultural practice but also as a political practice in that power operates at all levels in society in general (Foucault 1971, 1980) and in teacher-student interactions in particular.

\section{Agency and positioning}

To understand how discourses are exercised and how students are positioned, I draw not only on Foucault's $(1971,1977,2003)$ theories of discourse but also Burr's elaboration of agency (Burr, 2003). Here, agency is the dynamic capacity ${ }^{3}$ of humans to act independently and to make choices, though they may not always be aware of it. Agency is exercised in and as a result of social practice; it lies in the actions people take in response to particular discourses. Thus, in a Foucauldian sense, there is always room for collaboration, resistance and change.

Notions of positioning derive from "a conception of agency that acknowledges both the constructive force of discourse at a societal level as well as the capacity of the person to take up positions for their own purposes" (Burr, 2003, p. 188). In other words, both a student and a teacher can be agents, able to break up boundaries and adopt alternative ones, at the same time as various discourses may restrict either's participation in school mathematical practices.

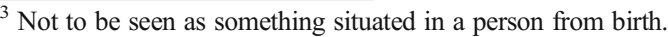


In this paper, the analytical focus is agency within discursive practices, in the sense that every discursive practice "implies a play of prescriptions that designate exclusions and choices" (Foucault, 1977, p. 199). Students' and teachers' choices are influenced by various and competing discourses, at the same time as their respective agencies affect discourse. Discourses affect the positioning of students both in their own performed acts of agency and in the actions performed by teachers and classmates. In other words, acknowledging the range of positions available to students in their mathematical interactions, I am interested in how multilingual students position themselves in discourses, and how others position them, in the mathematics classroom discourses.

\section{Data collection and analyses}

The study reported here took place in a first grade multilingual classroom in a school serving approximately 250 students ranging from kindergarten to grade five (aged 6-12). Eighty percent of the school population had minority backgrounds and spoke first languages that included Arabic, Sorani, Kurmancî, Turkish, Spanish, Farsi and Tigrinya. Of the 22 students in this particular class, some were born in Sweden of migrant parents while others had been born abroad and immigrated to Sweden at different ages. No student in the group was newly arrived; all had attended Swedish preschools the year before starting first grade and had some proficiency with Swedish. On the school's home page, as well as in a printed information folder, it was stated that the school uses language-oriented teaching ${ }^{4}$ in all school subjects and that the school has a mathematics workshop with hands-on material.

This paper draws on data from 12 mathematics lessons in which I was a participant observer. Participant observation entails getting close to the activities and everyday experiences of other people (Emerson et al., 1995). In this case, this meant getting close to the daily communication and activities of the mathematics classroom or, importantly, its discursive practices. Field notes were made at each observation and rewritten later the same day. Initial interpretations were categorised as either inclusive or exclusive discourses according to how students' experiences and initiatives were valued and accepted as resources for learning. These categories were later elaborated against evidence of students' demonstrations of agency in various exercised discourses. Data also comprised six interviews undertaken with the mathematics teacher, whom I call Anna, before and after some of the observed lessons, to elicit her perspectives on mathematics teaching, mathematics learning and how she planned her lessons. Informal talks with students over breaks and lunches gave a picture of their views on mathematics and language practices in the classroom. Anna's interviews were audio taped and contemporaneous notes were written for all interviews, whether formal or informal.

Agency is used both as an analytical tool for locating certain forms of interaction and communication in the classroom, and for locating students' activity and intentions in those interactions. Central questions in the analysis are: Which discourses are traceable in the activity? What are students expected to learn? How does Anna act to engage students and how do students act to learn what they are expected to learn? In what ways are students invited to act and how do their actions impact discourse? How are students positioned? The

\footnotetext{
${ }^{4}$ Integration of subject content knowledge and language learning, sometimes also called language sensitive teaching.
} 
analysis is directed towards the actions that Anna and the students perform in interactions. The analysis involves a representation of patterns, regularities and frequent themes. These traceable discourses have been related to performance of agency and vice versa. For example, a language-oriented discourse was seen to be operating when certain forms of interaction were going on, for example when a teacher changes plans for lessons, influenced by students' actions and positions as engaged in 'Swedish language issues' when doing mathematics.

In teachers' and students' classroom activity and interaction, various performances signify agency, such as who has the control over the content matter and who has the control over the way the content matter is dealt with in the classroom. Power relations are manifested in the interaction between students, their teacher and wider societal contexts, such as official and traditional discourses. An aspect of this is how students contribute to the process of determining what will be legitimised as valuable knowledge in the mathematics classroom. The power to define this is usually assigned to the teacher, but in social interaction, students' agency may change power relations and influence the defining of valued knowledge and thus production of knowledge. As agency is enacted, teachers and classmates position students, at the same time as students are positioning themselves, as knowledgeable and engaged students in certain discourses operating in the classroom. Students can also act with resistance as a way to perform agency.

I will give an account of the findings in terms of discourse. In the analyses, I draw on discourses derived from earlier research and official documents like the National Curriculum (Skolverket, 1994). The discourses are named as follows: (a) language-oriented discourse drawing on Hajer (2003) and Lindberg (2009) supporting second language learners' acquisition of Swedish through language-orientated teaching in mathematics, (b) reform-oriented discourse characterised by emphases on communication and collaboration (Moschkovich, 1999) and (c) traditional school mathematical discourses referring to what Mellin-Olsen (1987) named traditional ways of teaching mathematics as "task-discourse", a task is then the centre-piece of attention and activity. A traditional discourse is also in line with Skovsmose's (2001) "exercise paradigm" where mathematical ideas and techniques are presented on the blackboard, and some examples are shown. Thereafter, students solve exercises usually in a textbook. Teachers ask students for what they already know, and students answer the way teachers expect them to do, (d) normalising monolingualism (Gruber, 2007), Swedish-ness, (Runfors, 2003) and self-motivated students (Skolverket, 1994), and (e) promoting students' life experiences discourses (Moschkovich, 2002).

The "voice of the" institutions is recognised in official documents. Official documents have been analysed with regard to mathematics teaching and language policies.

\section{Mathematical discourses in the Swedish national curriculum}

The Swedish national syllabus in operation at the time of data collection recommends that teachers exploit communicative inquiry teaching. One aim of which was to give pupils the opportunity to

practice and communicate mathematically in meaningful and relevant situations through actively and openly searching for understanding, new insights and solutions to different problems. (Skolverket, 1994, p. 23) 
More recently, it is expected that mathematics teaching

should help pupils to develop their ability to argue logically and apply mathematical reasoning. Pupils should through teaching be given the opportunity to develop familiarity with mathematical forms of expression and how these can be used to communicate about mathematics in daily life and mathematical contexts. (Skolverket, 2011, p. 62)

Such communicative and argumentative expectations, I argue, reflect a mathematic reformoriented discourse (Moschkovich, 1999; Boaler \& Greeno, 2000). However, national evaluations (Skolverket, 2004, 2012) show that only about $6 \%$ of time in mathematics classes is committed to inquiry-based approaches to learning, a problem exacerbated by the fact that not only has the time spent on whole class instruction decreased over the last 10 to 15 years but that group work is rare. Many Swedish teachers continue to teach in traditional ways, despite the curriculum's reform emphases, with the most commonly used artefact being the textbook. As a recent national report noted,

By far the most common working method is that students sit and work individually with textbook data, called 'individual counting', and that teacher goes around and helps them. Teachers of mathematics are also the teachers were the least likely state that they are linking teaching (mathematics) to society and life outside school. (Skolverket, 2012, p. 17)

In a multilingual mathematics classroom, where students may speak a range of first languages, both reform and traditional discourses have important consequences. The communicative and argumentative nature of the former demands a linguistic competence in Swedish. Individual work from textbooks, the dominant traditional school mathematical discourse in Sweden, makes its own significant, though different, language demands because students have to interpret and respond to written tasks. In other words, both reform- and traditional-oriented practices place not inconsequential demands on the second language learner.

\section{The official language policy in Sweden}

According to national guidelines, students are entitled to tuition in any subject in their mother tongue and tuition in Swedish as a second language if one or both parents have a mother tongue other than Swedish and this language is frequently used in their homes (Skollagen, $1985)^{5}$. Moreover, teaching interventions should acknowledge "the diversity of languages the multilingual children and students bring to preschool and school" (Skolverket, 2002, p. 6), not least because having "access to their native language also facilitates language development and learning in different areas" (Skolverket, 2011, p. 83). Within this official discourse, a person's identity is seen as inextricably tied to his or her language (Skolverket, 1994, 2011). Consequently, a students' mother tongue can be studied as a subject in the national school curriculum, as this enables students not only to develop their ability to "formulate and communicate verbally and in writing" but also to "use their mother tongue as a medium for their language development and their learning" (Skolverket, 2011, p. 87). This right to study their mother tongue has been in place since 1968. In sum,

\footnotetext{
5 In English, Education Act.
} 
Language is the primary tool human beings use for thinking, communicating and learning. Through language people develop their identity, express their feelings and thoughts, and understand how others feel and think. Rich and varied language is important in being able to understand and function in a society where different cultures, outlooks on life, generations and language all interact (Skolverket, 2011, p. 83).

Throughout these documents, students' mother tongues are legitimised as a resource for teaching and learning, reflecting an official discourse in which multilingualism is both valued and promoted. However, despite such language-oriented policies, students' mother tongues as resources for learning are usually not acknowledged in the practices of Swedish multilingual classrooms (Skolverket, 1997; Haglund, 2005, Norén, 2010). The obstacle to policy implementation seems to be attitudes, as described above in earlier Swedish research. Those attitudes are often grounded in an unawareness of three aspects in relationship to the importance of mother tongue maintenance, which is for identity and learning and as a part of a student's life.

\section{Enacted discourses in the mathematics classroom}

In the following, drawing on a range of data sources, I offer a brief summary of how Anna enacts the above discourses in her particular grade one classroom. Reflecting the reform focus of the curriculum, Anna often encouraged students to use different "hands on" materials like Cuisenaire rods, multilink, scales and calculators. In addition, her lessons were regularly structured around mathematical tasks that were solved in small groups or pairs. In such group circumstances, students were encouraged to discuss what they were doing. Her purpose, she said, was not only to illuminate mathematical meaning but also to encourage the use of Swedish words for mathematical concepts. Following this group work, Anna would discuss with her students - in small group, half or full class discussion - the mathematics involved. The language used was always Swedish, indicating that Anna did not explicitly promote her students' use of mother tongues. Her failure to promote the use of languages other than Swedish, despite the official discourse, can be interpreted as an impact of a normalising Swedish-ness discourse (Runfors, 2003). Throughout, Anna tries to keep her mathematics lessons varied; she rarely uses textbooks and students work alone for only short periods of time. Her organisation of mathematical content, lesson time and space conform to reformoriented expectations, which appear to contrast with the typical Swedish mathematics classroom (Pettersson, 1993; Skolverket, 2004, 2012; Palmer, 2005; Johansson, 2006; Persson, 2007; Kling-Sackerud, 2009).

Anna's activity choices not only impacted in various ways on students' agency but through the ebb and flow of power relations (Meaney, 2004), impacted on knowledge production as the consequence of that agency. A particular aspect of this was seen in the ways she encouraged communicative activities, through which students were enabled to contribute to a shared knowledge production. For example, in accordance with the Swedish national curriculum argument that "Students collect experiences from the outside world and thus have a basis to broaden their mathematical skills" [Eleverna hämtar erfarenheter från omvärlden och får därmed underlag för att vidga sitt matematiska kunnande] (Skolverket, 2009, p. 6), Anna exploited students' out-of-school experiences as starting points for their learning of mathematics. She did not see her students as "tabula rasa" (Stathopoulou \& Kalabasis, 2007) but 
exercised a language-oriented discourse in which student experiences related to the learning of both mathematics and the Swedish language were valued. In such discourses, multilingual students can be positioned and position themselves as engaged and competent mathematics learners (Moschkovich, 2002, 2007a, b).

\section{Language-oriented discourse, mathematics and agency—-teen and ton ${ }^{6}$}

Every morning, Anna greeted her students individually as they entered the classroom. It was an occasion when out-of-school experiences could be shared and occasionally resulted in changes to her planned mathematical activities. In such changes, I see Anna promoting student agency through a shift in power relations. A second example, in which Anna facilitated student agency through a redistribution of power, was observed in her engagement with two girls, Liljana and Amina. The girls had been discussing whether becoming a teenage necessarily entailed becoming "fussy" [fjantig]. The girls told Anna that one of their teenage sisters and some neighbouring girls had become fussy and that they never wanted to become fussy themselves. Amina asked Anna:

1. Amina: Do you really have to become fussy when you become a teenager? [Måste man bli fjantig när man blir tonåring?]

2. Anna: What do you mean? Do you know anyone that is fussy? [Vad menar du? Känner du någon som är fjantig?

3. Amina: My neighbour, she has strange clothes and ... [Min granne, hon har konstiga kläder och ...]

4. Liljana: My sister and cousin as well ... [Min syster och kusin också ...]

5. Anna: How old are they then? How old are you when you are a teenager? What is a teenager? [Hur gamla är dom då? Hur gammal är man när man är tonåring? Vad är en tonåring?]

6. Amina: They can be 15 or 19. [Dom kan vara15 eller 19]

7. Liljana: Between 12 and 14. [Mellan 12 och 14]

In the above, Anna used the girls' conversation to explore their understanding of the suffix, ton (utterance 5). Anna had inferred, from utterances 6 and 7, that neither knew that a teenager's age is derived from the words thirteen through nineteen. That is, while they knew all the counting words from ten to twenty, they had not linked the suffix ton to the prefix in tonåring. This was a connection that Anna wanted them to understand, not least because she wanted the girls to realise that people are teenagers from thirteen to nineteen years of age and learn the appropriate Swedish words. In so doing, Anna used the mathematical content to focus on the vocabulary as part of what appeared to be the strong language-oriented discourse promoted by the national curriculum. In a Foucauldian sense, Anna's language-oriented discourse had not only become a "norm" but one in which students were strongly socialised. It was also an indication of an inclusive discourse, as the girls' curiosity, stimulated outside the classroom, was taken seriously and legitimised for knowledge production inside the classroom. In sum, Anna socialises her students into both language-oriented and mathematical discourses. Her teaching activities seem frequently designed to address specific Swedish vocabulary

\footnotetext{
${ }^{6}$ The Swedish word for teenager is tonåring. The suffix ton, just like teen in English, refers to ten in all numbers from 13 through 19- tretton (13), fjorton (14) and so on. The Swedish word for year is år.
} 
related to concepts in primary mathematics. Her inclusion of students' inquiries and classroom responses, which accords with sociocultural views on students' prior knowledge as resources for teaching and learning mathematics (Moschkovich, 2007a, 2011), reflects a reform-oriented discourse that seemed to support students' agency, at the same time as students' agency maintained a reform-oriented school mathematical discourse.

\section{A dominant (normalising) language-oriented discourse — valued ways of acting}

As the lesson proceeded, eight more students were asked, one by one, to figure out how old a teenager can be. They give varying suggestions, but no one said thirteen to nineteen. Anna seemed concerned about their conceptualisation of teen in relation to the Swedish language. Again she asked for suggestions. Tony, suddenly changing his mind, said that he had guessed" before but "now I know! [Nu vet jag!]". He asked Anna to write the numbers from eleven to nineteen "in words" on the white board and so she does. When Anna asked him why he wanted her to write those numbers he answers, "Ten is not a teen [Tio är inte ett ton]".

In this episode, as an element of a particular discursive practice, two discourses exist side by side. Tony's manifestation of agency, enabled by the exercise of both language-oriented and reform-oriented mathematical discourses, positioned him as both mathematically and linguistically competent. Moreover, in writing the numbers on the white board, Anna legitimised Tony's proposition as a resource for further learning, not only for Tony but also for other students. Anna did not see Tony's intervention as a challenge to her authority, but, by conceding Tony's position as competent, transferred authority to him and, as a consequence, enabled the production of shared knowledge and the tacit negotiation of power relations.

Next, Anna turned to her students, pointed to the white board and a few of the written -teen suffixes, and asked:

8. Anna: What can we say about these numbers? [Vad kan vi säga om dessa tal?]

In so doing, Anna, in a shift of responsibility from the individual to the group, now spoke of "we". Her students remained quiet. Anna looked at Tony and asked him to come to the white board. On his way, Tony picked up a pointer and then, pointing to each word from thirteen to nineteen in turn, said:

9. Tony: There it says teen, there it says teen, /.../ there it says teen, it says teen the whole row. [Där står det ton, där står det ton, / . ./ där står det ton, det står ton på hela raden]

After, which Anna wrote the word teenager [tonåring] on the board.

Anna's discursive practice not only "allowed" Tony to point to all of the -teen names written on the white board but provided him with the authority to take initiative and agency. In so doing, he was positioned, by both his own actions and Anna, as a knowledgeable student engaged in both the co-construction of knowledge and the teacher's role, agentic actions entirely in accord with his being seen as competent within both mathematical and language-

\footnotetext{
${ }^{7}$ Guessing could be interpreted as a "norm" in some mathematics classrooms where it is better to guess than not give an answer at all in a discourse where "anything goes" (Björklund Boistrup, 2010).
} 
oriented discourses. His competence, in both regards, was confirmed by his agentic decision not to point to eleven and twelve. Throughout, Anna authorised his actions by nodding. This can be interpreted as an episode in which the relational power in a discursive practice is dynamic.

Thus far, the content of the lesson had been built on the earlier conversation of Liljana and Amina. The issue about sisters, cousins and other female teenagers being fussy or not had been transformed into a joint exploration of mathematical words' multiple meanings. However, Anna, through Tony's and other students' agentic interactions, reconstructed the exploration into a "project" focused on expectations concerning mathematical learning within the context of Swedish language learning, expectations entirely appropriate for first grade students learning in their second language. Throughout, Anna acted in accordance with a languageoriented discourse. However, she also seemed to encourage other, normalising, discourses. For example, her use of "we" (utterance 8) alluded to a collective discourse (Walkerdine, 1988; Cotton \& Hardy, 2004), while her failure to make any reference to her students' first languages appeared to reflect a Swedish-ness discourse: in our classroom "we" [the Swedes] speak (Swedish).

Another boy who in knowledge production affected power relations through the enactment of agency was Melvin. He suggested that ton (teen) could designate something else:

10. Melvin: But ... this thing about ton, one ton, two tons, three tons ... what is that?

[He pauses for a short while]. It is like this ... (he points to the table). This weighs a ton!

[Men ... det här om ton, ett ton, två ton, tre ton ... vad är det? (Han funderar en kort

stund). Det är så här ... (han pekar på bordet). Det här väger ett ton!

In this instance, in "allowing" a change of direction to her planned lesson, Anna facilitated a continuation of the language-oriented discourse. Melvin's question prompted a new but relevant focus on the word ton as a unit of measure for weight - in Swedish ton is the same word for both teen and ton. As she did with Tony, Anna not only "allowed" Melvin to show his language awareness connected to Swedish and mathematical content but also confirmed his position as competent by smiling and nodding encouragingly. In so doing, she supported Melvin's agency by including and encouraging his curiosity within the mathematical reform discourse. He continued by suggesting that it is possible to weigh oranges and flour. Within the discourse, Anna's following question made it possible for Melvin to move around the classroom and collect a scale used for measuring for example flour. Anna, accepting his movement, asked him what he thought oranges might weigh.

11. Melvin: (quietly to himself) One kilogram, two kilograms ... (Melvin puts the scale on the table were the students were sitting). (tyst för sig själv) [Ett kilo, två kilos ... (Melvin ställer vågen på bordet där de andra eleverna sitter)].

Anna repeated Melvin's suggestion and wrote 1 kilo [1 kg] on the whiteboard, not hearing Amir, in a low voice, suggest that "there are also grams [det finns också gram]" and "oranges can weigh a kilo [apelsiner kan väga ett kilo]". At this point a girl, Muna, added "There are degrees ... I am thinking of degrees. [Det finns grader ... Jag tänker på grader].

Although Muna's suggestion did not lead Anna to change the direction of her lesson, the posing of the question, reflecting a tacit permission to voice an individual mathematical thought, showed Muna being positioned in a reform mathematical discourse. Also, her question prompted Liljana, confirming the reform-oriented mathematical discourse, to ask another question related to "four grams of butter [fyra gram smör]" when making cakes. Such 
actions, despite her not acting on them, can be construed as reflecting Anna's commitment to enacting a Swedish language-oriented discourse. The lesson continued:

12. Anna: Actually, it is like this ... kilogram [Det är faktiskt så här ... kilogram].

Anna wrote the word kilogram on the whiteboard, pointed to the end of the word and drew a line below the suffix, gram. She did not respond to the girls' utterances. Amir on the other hand was deeply involved in a language-oriented discourse:

13. Amir: You have to look at and connect the first letter [Du måste titta på och koppla ihop med den första bokstaven].

Anna did not pay attention to what Amir was saying either; she was transforming to exercise of a mathematical discourse.

14. Anna: The unit (that we use) when we weigh is called a kilo. We say kilo. What do we say when we talk about an elephant, what do we use when we weigh an elephant? Can I say gram (write g on the whiteboard) or am I going to say kilo (writes kilo) or gram (points to g) when I speak about elephants? [Enheten (som vi använder) när vi väger kallas ett kilo. Vi säger säger kilo. Vad säger vi när vi pratar om en elefant, vad använder vi när vi ska väga en elefant? Kan jag säga gram (skriver g på whiteboarden) eller ska jag säga kg (skriver kg) eller gram (pekar på g) när jag pratar om elefanter?]

Having asked, one by one, what her students thought, Anna turned to Melvin, in much the same way as with Tony earlier, to answer the question. In so doing, it seemed that Anna was positioning Melvin as the most mathematical competent child. He replied, "ton", leading, as a consequence of Melvin's agency, all other students expect Cecilia, to answer "ton". Interestingly, the single dissenting voice, Cecilia, said she wanted "to think about it" as she hadn't "decided yet". Such actions confirmed Melvin being positioned, by himself, Anna and now the class, as a committed and authoritative learner in reform-oriented mathematical and language-oriented discourses, which were enacted side by side. Also, it could be argued that Cecilia, like Muna, Liljana and Amir before her, while asserting the agentic individual voice of Anna's promoted reform-oriented mathematical discourse, found herself in a power relational knowledge production in which Melvin's view was "endorsed" and ultimately privileged. As with the episode earlier, Anna's repeated use of the word "we" (utterance 14) may be construed as encouraging either a normalising mathematical discourse, "this is how we do" mathematics, or a normalising social discourse related to Swedish-ness, "this is how we (the Swedes) do it". Anna seemed to address the whole group, "we" as Swedish school children and "we" "as mathematicians" at the same time as promoting the voices of individual students.

\section{Discussion}

\subsection{Exercise of various discourses, positioning and students' agency}

My aim for this study was to explore discursive practices in a multilingual mathematics classroom in order to understand how students' acts and positions relate to various discourses exercised in different practices. This was framed by the question, how do the various discourses operate and how do they relate to students' agency and positioning? 
The evidence indicated that various discourses operated and were exercised simultaneously. The mathematical discourse, typically reform-oriented, created positions and space for students' agency. For example, Amina's and Liljana's out-of-school experiences initiated changes to lesson plans. Students "took the floor" and thus initiated shared production of knowledge. When Tony picked up a pointer on his way to the white board and Melvin grabbed some weighing scales, both boys were positioned, by themselves and Anna, as both engaged mathematics learners and teachers. Students' experiences from out of school were acknowledged and, to some extent, exploited for mathematical content-related discussions in languageoriented discourses that valued students' informal language as a means of expressing mathematical ideas (Setati \& Adler, 2000).

The students in this study initiated investigations and resonated. This, it can also be said, may have produced self-confident mathematics learners that were used to take action for their own learning, and produced knowledge in interactions. Even though the teacher allocated turns, students' agency "made" her change lesson directions and content more than once, due to interactive power relations. Teacher control may not be an explanation of students' success or failure, rather it was the discursive practices that positioned students as engaged mathematics learners in this classroom.

Students positioned themselves by manifesting and communicating how their experiences could be vehicles for discussing different subject matter in mathematics lessons. Some of the students treated knowledge in their own ways and became masters of the content and the discourse changes. The use of only Swedish reflects contexts in the wider society. As Lindberg (2009) pointed out, the use of language-oriented methods and content language learning in school subjects is just one aspect of teaching in Swedish multilingual schools today. An interesting finding in this study is that the focus on Swedish language learning, through mathematical content, enhanced reform-oriented pedagogy. And an emphasis on reformoriented pedagogy seemed to support the learning of a second language and mathematics simultaneously.

Furthermore, it seemed as though the language-oriented discourse opened up a discourse that normalised Swedish-ness at the same time as it supported reform-oriented school-mathematical discourse. The supportive relationship operated alongside the on-going processes of normalisation whereby students' mother tongues continue to be subordinated or ignored (León Rosales, 2010). The language-oriented discourse was strongly promoted only in relation to the Swedish language (Sjögren, 1996, 1997), even though multilingualism is promoted in official policy. In Barwells' (2009) words, tensions between student's mother tongue and the language of instruction are at hand, but not showing in the classroom interactions. The students' experiences of being bilingual persons were mostly ignored. Consequently, their full identities may have been denied (Foucault, 1972), thus imposing monolingualism on the bilingual young students. Though the students in this study brought resources to the school mathematical discourse and those resources were used as a base for learning mathematics, Anna could have used also other linguistic resources and asked the students about, for example, the words in the number line from ten to twenty in their mother tongues, and comparisons would have been possible. In most languages, the age of adolescents cannot be related to words in the number line.

\subsection{What is the contribution of the Foucauldian framework?}

The Foucauldian framework, also elaborated by Burr (2003), has helped me explore how various discourses operated in a multilingual mathematics classroom, and how agency and 
positions were made available. By studying discursive practices, what is said and done, and what is included and excluded in the classroom, it was more observable how action possibilities were manifested. Emphasising how mathematics subject content took shape, and how knowledge was co-produced, enables a discussion of how young multilingual students recognise themselves in relation to the world and to other people (Popkewitz, 1987). To encourage young students to become or to take up positions as engaged mathematics learners, a certain way of socialisation is noticeable. The use of a Foucauldian framework also made power relations detectable as a web of interactions. In other words, relational power circulated discursively in interactions between teacher and students. Power was productive while knowledge derived from students' earlier experiences and new knowledge (derived from both students and teacher) offered were used to co-produce new knowledge.

\subsection{Concluding reflections}

The tension between the official mathematical discourse and the traditional discourse documented in Swedish mathematics education (Pettersson, 1993; Skolverket, 2004, 2012; Palmer, 2005; Johansson, 2006; Persson, 2007; Kling-Sackerud, 2009) seemed to diminish in this classroom, when a reform-oriented mathematical discourse and a language-oriented discourse worked simultaneously.

The students were not explicitly identified as immigrants in the classroom practice. They were treated as though they were Swedish students. However, the language-oriented discourse in the classroom categorised them as immigrants in a more implicit way. As the school had a high percentage of multilingual students and was situated in a segregated suburb, the whole school was categorised as an immigrant school, and thus could be marginalised. As well, every school, which announces that language-oriented methods are used in all school subjects, would be categorised as an immigrant school, in discursive practice of normalising. Students positioned as immigrant students in immigrant schools need language-oriented methods; "normal" Swedish students do not need language-oriented methods. The categorisation reflects a normalisation discourse at a macro level and maintains the dichotomous picture around students with foreign backgrounds and their schooling.

Furthermore, the supportive relationship operating alongside the on-going processes of normalisation whereby students' mother tongues continue to be erased or ignored gave space to students' agency and mathematical communication in the classroom. The intersection of discourses promoted students' participation in school mathematical practices. Thus, a more language-oriented discourse in general in multilingual as well as in mainstream mathematics classroom might affect the classrooms towards a more reform-oriented mathematical discourse. There is potential for students' agency to be realised in reformoriented mathematical and language-oriented discourses, in the same way as the intersection of discourses at play in this study positioned student as agentic mathematics learners. There seemed to be space for creative changes within the mathematical discourse in which these multilingual students operated. The agentic voices of the students represent hopes for changes to also include other languages and cultures than Swedish, in multilingual mathematics classrooms.

Acknowledgements I would like to thank three anonymous reviewers and Paul Andrews for providing scientific guidance in the writing of this article. 


\section{References}

Adler, J. (2001). Teaching mathematics in multilingual classrooms. Dordrecht: Kluwer Academic Press.

Barwell, R. (2005). Integrating language and content: Issues from the mathematics classroom. Linguistics and Education, 16, 205-218.

Barwell, R. (2009). Multilingualism in mathematics classrooms: An introductory discussion. In R. Barwell (Ed.), Multilingualism in mathematics classrooms. Global perspectives (pp. 1-13). Nort York: Multilingual Matters.

Björklund Boistrup, L. (2010). Assessment discourses in mathematics classrooms: A multimodal study. Published doctoral thesis. Stockholm: Stockholm University.

Boaler, J., \& Greeno, J. (2000). Identity, agency, and knowing in mathematics worlds. In J. Boaler (Ed.), Multiple perspectives on mathematics learning and teaching (pp. 171-200). Westport: Ablex Publishing.

Burr, V. (2003). Social constructionism. London: Routledge.

Civil, M. (2002). Culture and mathematics: A community approach. Journal of Intercultural Studies, 23(2), 133-148.

Clarkson, P. (2007). Australian Vietnamese students learning mathematics: High ability bilinguals and their use of their languages. Educational Studies in Mathematics, 64(2), 191-215.

Cotton, T., \& Hardy, T. (2004). Problematizing culture and discourse for mathematics education research. Defining issues; tools for research. In P. Valero \& R. Zevenbergen (Eds.), Researching the socio-political dimensions of mathematics education. Issues of power in theory and methodology. Boston: Kluwer Academic Publishers.

Cummins, J. (1979). Cognitive/academic language proficiency, linguistic interdependence, the optimum age question and some other matters. Working Papers on Bilingualism, 19, 198-205.

Cummins, J. (1996). Negotiating identities: Education for empowerment in a diverse society. Ontario: California Association for Bilingual Education.

Cummins, J. (2000). Language, power and pedagogy: Bilingual children in the crossfire. Clevedon: Multilingual Matters.

Cummins, J. (2008). BICS and CALP: Empirical and theoretical status of the distinction. In B. Street \& N. Hornberger (Eds.), Encyclopedia of language and education, volume 2: Literacy (pp. 487-499). New York: Springer.

Emerson, R. M., Fretz, R. I., \& Shaw, L. L. (1995). Participant observation and fieldnotes. In P. Atkinson, A. Coffey, S. Delamont, J. Lofland, \& L. Lofland (Eds.), Handbook of ethnography. London: Sage.

Foucault, M. (1971). Diskursens ordning [The order of Discourse]. Stehag: Brutus Östlings förlag.

Foucault, M. (1972). The archaeology of knowledge. London: Tavistock.

Foucault, M. (1977). History of systems of thought. In D. F. Bouchard (Ed.), Language, counter-memory, practice: Selected essays and interviews by Michel Foucault (pp. 119-204). Ithaca: Cornell University Press.

Foucault, M. (1980). Power/knowledge: Selected interviews and other writings 1972-1977. London: Harvester.

Foucault, M. (1982). After the word: the subject and power. In H. Dreyfus \& P. Rabinow (Eds.), Michel Foucault: Beyond structuralism and hermeneutics. London: The Harvester.

Foucault, M. (1991). Discipline and punish: The birth of the prison. London: Penguin.

Foucault, M. (2003). In P. Rabinow \& N. Rose (Eds.), The essential Foucault: Selections from The Essential Works of Foucault, 1954-1984. New York: The New Press.

Ganuza, N., \& Hedman, C. (2015). Struggles for legitimacy in mother tongue instruction in Sweden. Language and Education, 29(2), 125-139.

Gruber, S. (2007). Skolan gör skillnad: Etnicitet och institutionell praktik. [School makes a difference: Ethnicity and institutional practice]. Published doctoral thesis. Linköping: Linköpings universitet.

Haglund, C. (2005). Social interaction and identification among adolescents in multilingual suburban SwedenA study of institutional order and sociocultural change. Published doctoral thesis. Stockholm: Centre for research on Bilingualism, Stockholm University.

Hajer, M. (2003). Språkutvecklande ämnesundervisning - ett andraspråksperspektiv i alla ämnen [Language Developing subject teaching - a second language perspective in all subjects]. Symposium 2003-Arena andraspråk [Symposium 2003-Arena second language]. Nationellt centrum för svenska som andra språk. Stockholm: HLS Förlag.

Hardy, T. (2004). "There's no hiding place": Foucault's notion of normalization at work in a mathematics lesson. In M. Walshaw (Ed.), Mathematics education within the Postmodern. Greenwich: Information Age Publishing Inc.

Johansson, M. (2006). Teaching Mathematics with textbooks: A classroom and curricular perspective. Published doctoral thesis. Luleå: Luleå University of Technology. 
Jones, D. V. (2000). Talk and texts in bilingual mathematics lessons in Wales. The Welsh Journal of Education, 9(2), 102-119.

Khisty, L. L. (1995). Issues of language and meanings in mathematics teaching with Hispanic students. In W. G. Secada, E. Fennema, \& L. B. Adajian (Eds.), New directions for equity in mathematics education (pp. 279297). Cambridge: Cambridge University Press.

Kling-Sackerud, L-A. (2009). Elevers möjligheter att ta ansvar för sitt lärande $i$ matematik: En skolstudie $i$ postmodern tid. [Pupils' ability to take responsibility for their learning in mathematics: A school study in postmodern times.] Published doctoral thesis. Umeå: Teknisk- naturvetenskaplig fakultet, Matematik, teknik och naturvetenskap. Umeå University.

León Rosales, R. (2010). Vid framtidens hitersta gräns—om maskulina elevpositioner i en multietnisk skola [At tomorrow's closest limit—on masculine pupil positions in a multi-ethnic school]. Published doctoral thesis. Tumba: Mångkulturellt Centrum.

Lindberg, I. (2009). I det nya mångspråkiga Sverige [The new multilingual Sweden]. Utbildning \& Demokrati [Education \& Democracy], 2, 9-38.

Meaney, T. (2004). So what's power got to do with it? In M. Walshaw (Ed.), Mathematics education within the Postmodern (pp. 181-199). Greenwich: Information Age Publishing Inc.

Mellin-Olsen, S. (1987). The politics of mathematics education. Dordrecht: Kluwer Academic Publishers.

Moschkovich, J. (1999). Understanding the needs of Latino students in reform-oriented mathematics classrooms. In Secada, Walter G., et al (Eds.), Changing the faces of mathematics: Perspectives on Latinos (pp. 5-12). National Council of Teachers of Mathematics: 1906 Association Drive, Reston, 20191-159.

Moschkovich, J. (2002). A situated and sociocultural perspective on bilingual mathematics learners. Mathematical Thinking and Learning, 4(2\&3), 189-212.

Moschkovich, J. (2007a). Bilingual mathematics learners: How views of language, bilingual learners, and mathematical communication affect instruction. In N. Nasir \& P. Cobb (Eds.), Improving access to mathematics: Diversity and equity in the classroom (pp. 89-104). New York: Teachers College Press.

Moschkovich, J. (2007b). Using two languages when learning mathematics. Educational Studies in Mathematics, 64(2), 121-144.

Moschkovich, J. N. (2008). "I went by twos, he went by one": Multiple interpretations of inscriptions as resources for mathematical discussions. The Journal of the Learning Sciences, 17(4), 551-587.

Moschkovich, J. (2011). Methodological issues in research on language and learning mathematics. In M. Setati, T. Nkambule \& L. Goosen, (Eds.), Proceedings of the ICMI Study 21 Conference, Mathematics and Language Diversity, Sào Paulo Brazil.

Moschkovich, J. (2012). How equity concerns lead to attention to mathematical discourse. In B. HerbelEisenman, J. Chopin, D. Wagner, \& D. Pimm (Eds.), Equity in discourse for mathematics education: Theories, practices, and politics. Dordrecht: Springer.

Norén, E. (2010). Flerspråkiga matematikklassrum: Diskurser i grundskolans matematikundervisning [Multilingual mathematics classrooms: Discourses in compulsory school's mathematics teaching]. Published doctoral thesis. Stockholm: Stockholms universitet.

Öhman, M. (2010). Analysing the direction of socialisation from a power perspective. Sport, Education and Society, 15(4), 393-409.

Otterup, T. (2005). “Jag känner mig begåvad bara.” Om flerspråkighet och identitetskonstruktion bland ungdomar i ett multietniskt förortsområde ["I just feel gifted." About multilingualism and identity construction among adolescents in a multiethnic suburban area]. Göteborgsstudier i nordisk språkvetenskap [Gothenburg Studies in Scandinavian Linguistics]. Published doctoral thesis. Göteborg: Göteborgs universitet.

Palmer, A. (2005). Matematik i förändring [Mathematics in change]. Stockholm: Master Thesis, Lärarhögskolan i [Teacher Education College in] Stockholm.

Parszyk, I.-M. (1999). En skola för andra: Minoritetselevers upplevelser av arbets- och livsvillkor $i$ grundskolan [A school for others: Minority Students' experiences of working and living conditions in elementary school]. Published doctoral thesis. Stockholm: HLS Förlag, Studies in Educational Studies 17.

Persson, E. (2007). Det smyger sig in hela tiden: om tankestilar och traditioner $i$ utbildningen för blivande matematiklärare [It creeps into all the time: on thinking styles and traditions of training for prospective mathematics teachers]. Stockholm: Licentiat thesis, Lärarhögskolan i Stockholm.

Pettersson, A. (1993). Den nationella utvärderingen i grundskolan våren 1992. Matematik, åk 5. Huvudrapport. Skolverkets rapport 14 [The national assessment in primary schools in spring 1992. Mathematics, Year 5. Main Report. National Agency's Report 14]. Stockholm: Skolverket.

Phillips Manke, M. (1997). Classroom power relations: Understanding student-teacher interaction. Mahwah: Lawrence Erlbaum Associates, Publishers. 
Popkewitz, T. (1987). The formation of school subjects: The struggle for creating an American institution. London: Falmer Press.

Runfors, A. (2003). Mångfald, motsägelser och marginaliseringar. En studie av hur invandrarskap formas $i$ skolan [Diversity, contradictions and marginalization: A study of how immigrant students are formed at school]. Published doctoral thesis. Stockholm: Prisma.

Ryve, A. (2011). Discourse research in mathematics education: A critical evaluation of 108 journal articles. Journal for Research in Mathematics Education, Vol, 42(2), 167-199.

Setati, M. (2008). Mathematics education and language: Policy, research and practice in multilingual contexts. Regular lecture at ICME-10. Retrieved the 10th of August 2010 www.icme10.dk/proceedings/pages/.../RL Mamokgethi_Setati.pdf.

Setati, M., \& Adler, J. (2000). Between languages and discourses: Language practices in primary multilingual mathematics classrooms in South Africa. Educational Studies in Mathematics, 43, 243-269.

Setati, M, Nkambule, T., \& Goosen, L. (2011). (Eds). Proceedings of the ICMI Study 21 Mathematics and Language Diversity, Sào Paulo Brazil.

Sjögren, A. (1996). En "bra” svenska? Om språk, kultur och makt [A “good” Swedish? On language, culture and power]. Botkyrka: Mångkulturellt Centrum.

Sjögren, A. (1997). Language and environment: A cultural approach to education for minority and migrant students. Botkyrka: Mångkulturellt Centrum.

Skollagen. (1985). Education Act 1985:1100. Stockholm: Regeringen.

Skolverket [National Agency of Education]. (1994). Läroplan för det obligatoriska skolväsendet, förskoleklassen och fritidshemmet [Curriculum for the compulsory school system, the preschool class and leisure time class]. Stockholm: Fritzes.

Skolverket [National Agency of Education]. (1997). Utvärdering i naturkunskap och matematik: Lärare $i$ grundskolan berättar [Assessment in science and mathematics: Teachers' in primary school narratives]. Stockholm: Skolverket.

Skolverket [National Agency of Education]. (2002). Flera språk-fler möjligheter-utveckling av modersmålsstödet och modersmålsundervisningen [Multiple languages-more options-development of language support and native language instruction]. Stockholm: Skolverket.

Skolverket [National Agency of Education]. (2004). Nationella Utvärderingen [National evaluation] 2003. Stockholm: Skolverket.

Skolverket [National Agency of Education]. (2007). Press message: the 14th of August. Andelen behöriga till gymnasieskolan är den lägsta på tio år [The proportion eligible for upper secondary school is the lowest in ten years]. Retrieved 101227: http://www.skolverket.se/sb/d/203/a/9642.

Skolverket [National Agency of Education]. (2009). Kursplan med Kommentarer till mål som eleverna lägst ska ha uppnått $i$ slutet av det tredje skolåret $i$ ämnena matematik, svenska och svenska som andraspråk [Syllabus with comments to goals that students must have attained a minimum of end of the third school year in mathematics Swedish and Swedish as a second language]. Stockholm: Skolverket.

Skolverket [National Agency of Education]. (2011). Curriculum for the compulsory school, preschool class and the leisure-time centre 2011. Stockholm: Skolverket.

Skolverket [National Agency of Education]. (2012). Utökad undervisningstid i matematik. Hur en ökning av undervisningstiden kan användas för att stärka elevernas matematikkunskaper [Increased instructional time in mathematics. How an increase in instructional time can be used to strengthen students' math skills]. Rapport 378. Stockholm: Skolverket.

Skolverket [National Agency of Education]. (2013). Skolor och elever i grundskolan 2012/13 [Schools and students in compulsory school]. Table 8B. Retrieved the 27th of November 2013 at http://www.skolverket. se/statistik-och-utvardering/statistik/grundskola/skolor-och-elever.

Skovsmose, O. (2001). Landscapes of investigation. ZDM, 33(4), 123-132.

Solomon, Y. (2007). Experiencing mathematics classes: Ability grouping, gender and the selective development of participative identities. International Journal of Educational Research, 46(1-2), 8-19.

Solomon, Y. (2008). Mathematical literacy: Developing identities of inclusion. New York: Routledge.

Stathopoulou, C., \& Kalabasis, F. (2007). Language and culture in mathematics education: Reflections on observing a Romany class in a Greek school. Educational Studies in Mathematics, 64(2), 231-238.

Thomas, W. P. \& Collier, V. P. (2001). A National Study of School Effectiveness for Language Minority Students' Long-Term Academic Achievement. Executive Summary. Center for Research on Education, Diversity \& Excellence (CREDE). www.crede.ucsc.edu/research/llaa/1.1 final.html.

Walkerdine, V. (1988). The mastery of reason. Cognitive development and the production of rationality. London: Routledge.

Walshaw, M. (2007). Working with Foucault in education. Rotterdam: Sense Publishers. 
Copyright of Educational Studies in Mathematics is the property of Springer Science \& Business Media B.V. and its content may not be copied or emailed to multiple sites or posted to a listserv without the copyright holder's express written permission. However, users may print, download, or email articles for individual use. 